\title{
USVL-360, a Novel Watermelon Tetraploid Germplasm Line
}

\author{
Amnon Levi ${ }^{1,2}$, Judy A. Thies, Patrick W. Wechter, and Mark Farnham \\ U.S. Department of Agriculture, Agricultural Research Service, U.S. \\ Vegetable Laboratory, 2700 Savannah Highway, Charleston, SC 29414
}

\author{
Yiqun Weng \\ U.S. Department of Agriculture, Agricultural Research Service, 1575 Linden \\ Drive, Madison, WI 53706
}

\section{Richard Hassell \\ Clemson University, Coastal Research and Education Center, 2700 Savannah Highway, Charleston, SC 29414}

Additional index words. breeding, Citrullus, resistance, root-knot nematode, rootstock

Seedless watermelons have become extremely popular, capturing over $90 \%$ of the U.S. watermelon market in recent years (United States Department of Agriculture Economics, Statistics and Market Information System, 2012). Seedless watermelons are triploid hybrids derived from a cross between tetraploid and diploid lines. Soilborne diseases and plant-parasitic nematodes have intensified in watermelon in recent years, particularly after the phase-out of the soil fumigant methyl bromide, and there is a continuous need to develop solutions for reducing disease and nematode pressure in this important cucurbit crop. Grafting of watermelons onto Cucurbita rootstocks as a means for reducing damage caused by soilborne diseases has been practiced throughout the world, particularly in Asia and the Mediterranean region. However, Cucurbita rootstocks are highly susceptible to root-knot nematodes (Thies et al., 2010, 2012, 2014) and can have an adverse effect on watermelon fruit quality (Cohen et al., 2014; Edelstein et al., 2014).

In previous studies, several U.S. PIs representing Citrullus lanatus (Thunb.) Matsum. \& Nakai var. citroides (L. H. Bailey) Mansf. (CLC) exhibited resistance to rootknot nematodes and/or fusarium wilt (Thies and Levi, 2007; Wechter et al., 2012). Recent genome sequencing and genetic analysis studies (Guo et al., 2013; Levi et al., 2012, 2013) showed that the CLC PIs contain unique genes or alleles that do not exist in red sweet watermelon cultivars. Among the genes unique to $C L C$, there are several nucleotide-binding site leucine-rich repeat gene sequence homologs that might be associated with disease or pest resistance (Harris

\footnotetext{
Received for publication 26 Sept. 2013. Accepted for publication 3 Jan. 2014.

We thank Drs. Nihat Guner and Xingping Zhang for their guidance in developing tetraploid lines. ${ }^{1}$ Research Geneticist.

${ }^{2}$ To whom reprint requests should be addressed; e-mailamnon.levi@ars.usda.gov.
}

et al., 2009). Also, many of the CLC PIs have a thicker crown and a larger vigorous vine compared with those of watermelon cultivars (Levi et al., 2012, 2013). Our recent studies in Charleston, SC (2009-12) showed that seedless (triploid) watermelon cultivars produced higher yield when grafted onto $C L C$ rootstocks compared with those grafted onto commercial squash (Cucurbita spp.) or Lagenaria siceraria (bottle gourd) rootstocks (Thies et al., 2010, 2012, 2014). Based on these results, we hypothesized that novel tetraploid $C L C$ lines would provide vigorous rootstocks with high protection against rootknot nematodes (RKN) for grafted watermelon scions compared with what could be provided by commonly used cucurbit rootstocks (e.g., bottle gourds or squash), which are highly susceptible to RKN (Thies et al., 2010,2012 , 2014). We also hypothesized that the close relationship between $C L C$ and the cultivated watermelon [Citrullus lanatus subsp. vulgaris Schrader ex Eckl. Et Zeyh. Fursa $(C L V)$ ] would ensure higher compatibility of rootstock and scion grafts, resulting in better watermelon fruit quality compared with squash and bottle gourd rootstocks.

\section{Origin}

USVL-360 is an autotetraploid ( $4 \mathrm{~N}=44$ chromosomes) derived from the U.S. PI $299379(2 \mathrm{~N}=22$ chromosomes $)$ collected in southern Africa. This watermelon accession has been designated a member of the "Tzama" watermelon group, also known as "cow watermelon," and it is classified as Citrullus lanatus (Thunb.) Matsum. \& Nakai var. citroides (L. H. Bailey) Mansf. (CLC), a group of ancient cultigens, also known as the 'Citron' melon. This classification is synonymous with Citrullus lanatus subsp. lanatus var. lanatus (Thunb.) Matsum. \& Nakai that is indigenous to southern Africa (Whitaker and Bemis, 1976; Whitaker and Davis, 1962).

Development of USVL-360 began in early 2010 at the USDA, ARS, U.S. Vegetable Laboratory, Charleston, SC, with greenhouse experiments aimed at converting CLC PI plants (diploids) into tetraploids. It continued with the evaluation of verified tetraploid plants (ultimately designated USVL-360) for growth habit, reproductive attributes and their potential for use as rootstocks for grafting with cultivated diploid (seeded) and triploid (seedless) watermelon scions.

USVL-360 is a pure line selection from an autotetraploid plant generated by treating a diploid CLC PI 299379 seedling with the herbicide Oryzalin (3, 5-dinitro-N4, N4dipropylsulfanilamide; Agrisel, Suwanee, GA). The application of $0.01 \%$ Oryzalin (on three consecutive mornings) to the apical meristem of young seedlings ( 3 to $5 \mathrm{~d}$ postgermination) arrested their growth, inducing differentiation of the apical meristem cells and regeneration of a tetraploid stem (Ascough et al., 2008; Contreras et al., 2010). When the regenerated stems (with apparent tetraploid attributes) began to flower in the greenhouse, they were self-pollinated. One putative tetraploid stem produced a fruit with 130 large $S_{1}$ $\left(\mathrm{T}_{2}=\right.$ second tetraploid generation) seeds with speckled light green-brown seedcoats (in contrast with smaller, light brown seeds from the diploid parent PI 299379; Fig. 1A). Flow cytometry, chromosome counting, and fluorescent in situ hybridization analyses of cells extracted from resulting $\mathrm{T}_{2}$ plants confirmed that they were tetraploids, verifying twice as much DNA per cell as normal diploids and a total of 44 chromosomes (Fig. 2). A $\mathrm{T}_{2}$ plant with tetraploid features, including large leaves with notched lobes and serrated edges (Fig. 1D), and female flowers with large dark yellow petals (Fig. 1B) was self-pollinated for three successive generations by single seed descent to ensure that the identified tetraploid selection $\left(\mathrm{T}_{5}\right)$ is homozygous.

\section{Description}

In field trials conducted in Charleston, SC, in 2013 (six replications $x$ three plants per plot), the resulting tetraploid USVL-360 plants had larger stem diameters (2.6 to 3.6 $\mathrm{cm}$ in diameter) compared with those of the diploid source parents ( 1.8 to $2.3 \mathrm{~cm}$ ). USVL360 has wide leaves with wide notched lobes and serrated edges (10.4 to $18.6 \mathrm{~cm}$ ) compared with those of the source diploid plant (8.1 to $14.3 \mathrm{~cm}$ ) (Fig. 1). The USVL-360 plants produced globular fruits (14 to $18 \mathrm{~cm}$ in diameter) with a light green-yellow rind and a dense green flesh, similar to the diploid parent PI 299379, but with significantly less seeds ( 65 to 110 vs. 280 to 400 seeds in the diploid parent) (Fig. 1).

After self-pollination in the greenhouse in Charleston, SC, USVL-360 plants produced 70 to 160 seeds per fruit; individual seed weight averaged $\approx 900 \mathrm{mg}$ per seed compared with the parental diploid seed weight of $500 \mathrm{mg}$ per seed. In addition, 7- to 10-d-old USVL-360 seedlings have larger cotyledons ( 2.7 to $3.1 \mathrm{~cm}$ width $\times 3.6$ to $3.9 \mathrm{~cm}$ length) than those of the diploid parent $(1.9$ to $2.1 \mathrm{~cm}$ width and 2.8 to $3.1 \mathrm{~cm}$ length). USVL-360 plants produce one large female flower for 

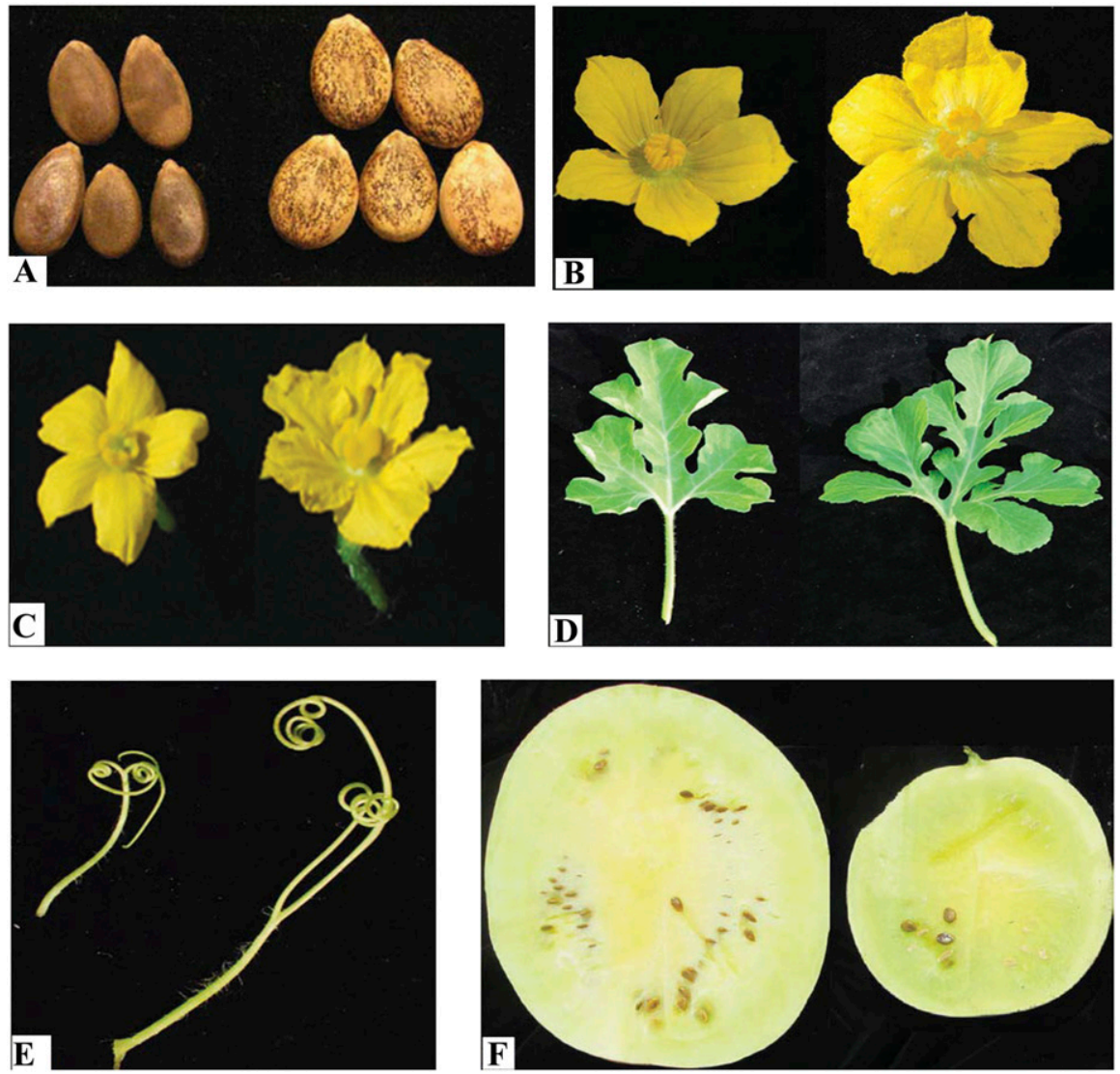

Fig. 1. Seeds (A), male flower (B), female flower (C), leaf (D), and tendril (E) of the diploid Citrullus lanatus var. citroides PI 299379 (left) vs. their counterparts showing larger features in the tetraploid derived line USVL-360 (right). Also, a cross-section (F) of the diploid PI 299379 watermelon (left) vs. USVL-360 (right) that produce smaller fruits with fewer but larger seeds.
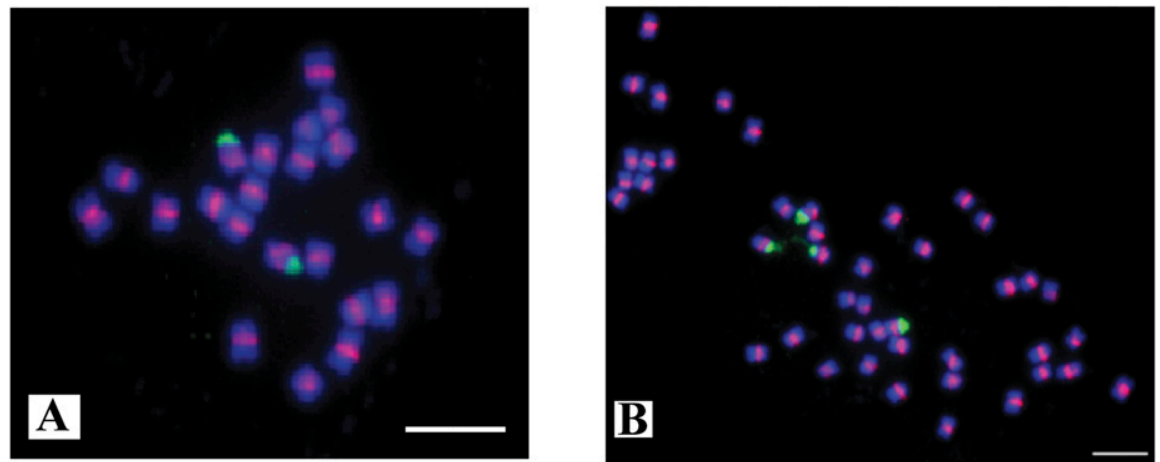

Fig. 2. Physical mapping of $45 \mathrm{~S}$ rDNA and centromeric tandemly repeated sequences on mitotic metaphase chromosomes (showing 22 chromosomes; A) of the Citrullus lanatus var. citroides PI 299379 and its tetraploid derived line USVL-360 (showing 44 chromosomes; B).

every seven to nine male flowers. The average diameter of open male and female flowers of USVL-360 is $2.7 \mathrm{~cm}$ and $3.1 \mathrm{~cm}$, respectively, whereas the diameter in the parental diploid is 1.8 and $2.0 \mathrm{~cm}$. Flowers of this line also have a yellow color with a slightly darker hue than that of the diploid parent (Fig. 1B-C).

Randomized complete block design experiments (five replications $\times$ three plants per plot) were conducted in Charleston, SC, in the summers of 2012 and 2013 to test USVL-360 and diploid $C L C$ lines as rootstocks for grafted seedless watermelon varieties 'Tri-X-313' or 'Melody', respectively.
As a rootstock for the grafted seedless watermelon Tri-X-313 scions, USVL-360 produced yields comparable to its diploid parent PI 299379 and the commercial CLC rootstock 'Ojakkyo' (e.g., 2.5, 2.4, and 3 fruits with total mean fruit weights of 18.17, 15.64, and $18.89 \mathrm{~kg}$ per plant, respectively) (Fig. 3). Although there were no significant differences among rootstocks in this experiment, the $C L C$ rootstocks produced higher yields than the cucurbit rootstocks 'Emphasis' bottle gourd (Lagenaria siceraria) (2.4 fruit per plant with a total mean fruit weight of $11.8 \mathrm{~kg}$ per plant) and 'Shintosa- Camel' and 'Strong
Tosa' hybrid squash (Cucurbita maxima $\times C$. moschata) (1.5 and 1.7 fruits per plant with mean fruit weights of $6.36 \mathrm{~kg}$ and $13.51 \mathrm{~kg}$ per plant, respectively). Similarly, in the summer of 2013, USVL-360 rootstocks produced yields comparable to the commercial $C L C$ diploid rootstock 'Ojakkyo' and the diploid parent PI 299379, and higher yields (although not significantly different) than the commercial cucurbit rootstocks 'Emphasis' and 'Shintosa Camel' when grafted with scions of the seedless watermelon variety 'Melody' (Table 1). The roots of 'Emphasis', 'Shintosa Camel', and 'Strong Tosa' were severely galled and roots of the USVL-360 rootstock had very few galls (Fig. 4). The high susceptibility of squash or bottle gourd rootstocks to $\mathrm{RKN}$ is most likely the reason for their overall poor performance compared with $C L C$ rootstocks (Thies et al., 2010, 2014). These results confirmed our hypothesis that a tetraploid $C L C$ rootstock could provide protection against RKN and might be a useful rootstock for grafted watermelon, producing watermelons with sufficient yield and quality. Still, additional studies in various locations across the United States, and possibly throughout the world, are needed to determine the effectiveness of tetraploid and diploid $C L C$ genotypes vs. squash or bottle gourd rootstocks for grafted watermelon.

In greenhouse experiments at the USDA, ARS, U.S. Vegetable Laboratory, Charleston, SC, during 2012, USVL-360 response to RKN infection was similar to that of its diploid $C L C$ parent PI 299379 and the CLC PI 500331, and superior to 'Charleston Gray' and the hybrid squash rootstock 'Strong Tosa' (Table 2). Our experiments in 2012 and 2013 in fields naturally infested with RKN confirmed the superior resistance of USVL-360 and its diploid CLC parent (PI 299379) over other commonly used cucurbit rootstocks (Fig. 4). An unreplicated greenhouse experiment indicated that the response of USVL-360 to fusarium wilt race 2 infection is similar to the response of its diploid parent (PI 299379) (47\% and 53\% of plants survived, respectively) and superior to the susceptible control checks 'Charleston Gray' and 'Sugar Baby' (13\% and $0 \%$ survived, respectively), which is similar to the results reported by Wechter et al. (2012).

USVL-360 is readily crossed with tetraploid lines derived from the cultivated type watermelon and may be considered a useful resource for breeding programs focused on enhancing resistance to soilborne diseases in tetraploid watermelon lines that are integral to the development of triploid-seedless watermelon varieties.

\section{Availability}

Small quantities of seed of USVL-360 are available for distribution to interested research personnel and plant breeders who make written request to Dr. Amnon Levi, U.S. Vegetable Laboratory, 2700 Savannah Highway, Charleston, SC 29414-5334 (amnon. levi@ars.usda.gov). Seed of USVL-360 will 


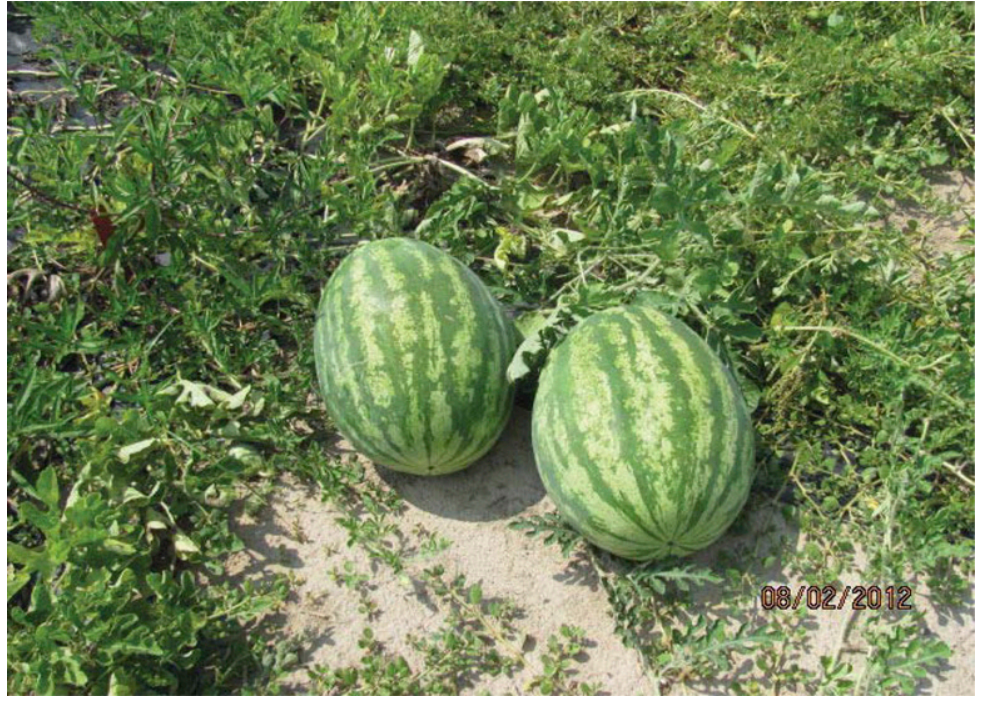

Fig. 3. Tri-X-313 watermelon fruits produced on a USVL-360 rootstock in a field in Charleston, SC (Summer, 2012).

Table 1. Total yield (kg per plant), number of fruit per plant, and soluble sugar content (Brix) of the seedless watermelon 'Melody' grafted onto rootstocks of the tetraploid line USVL-360, its diploid parent Citrullus lanatus var. citroides (CLC) PI 299379 (homozygous line 11129), the commercial $(C L C)$ rootstock Ojakkyo (OJ), the hybrid squash (Cucurbita maxima $\times$ C. moschata) rootstock 'Shintosa Camel' (SC), or the bottle gourd (Lagenaria siceraria) rootstock 'Emphasis' and self-grafted (M-SG), and non-grafted 'Melody' (M-NG) in a field experiment in Charleston, SC (Summer 2013).

\begin{tabular}{lccccccc}
\hline & USVL-360 & 11129 & OJ & SC & Emphasis & M-SG & M-NG \\
\hline Yield & $8.71 \mathrm{a}^{\mathrm{z}}$ & $7.66 \mathrm{a}$ & $7.61 \mathrm{a}$ & $5.41 \mathrm{a}$ & $4.55 \mathrm{a}$ & $7.64 \mathrm{a}$ & $6.45 \mathrm{a}$ \\
Fruits & $1.6 \mathrm{a}$ & $1.5 \mathrm{a}$ & $1.6 \mathrm{a}$ & $1.2 \mathrm{a}$ & $1.1 \mathrm{a}$ & $1.6 \mathrm{a}$ & $1.8 \mathrm{a}$ \\
Brix & $11.9 \mathrm{a}$ & $11.9 \mathrm{a}$ & $11.3 \mathrm{a}$ & $11.1 \mathrm{a}$ & $11.1 \mathrm{a}$ & $11.4 \mathrm{a}$ & $11.4 \mathrm{a}$ \\
\hline
\end{tabular}

${ }^{\mathrm{z}}$ Mean separation within rows by Fisher's protected least significant test, $P \leq 0.05$.

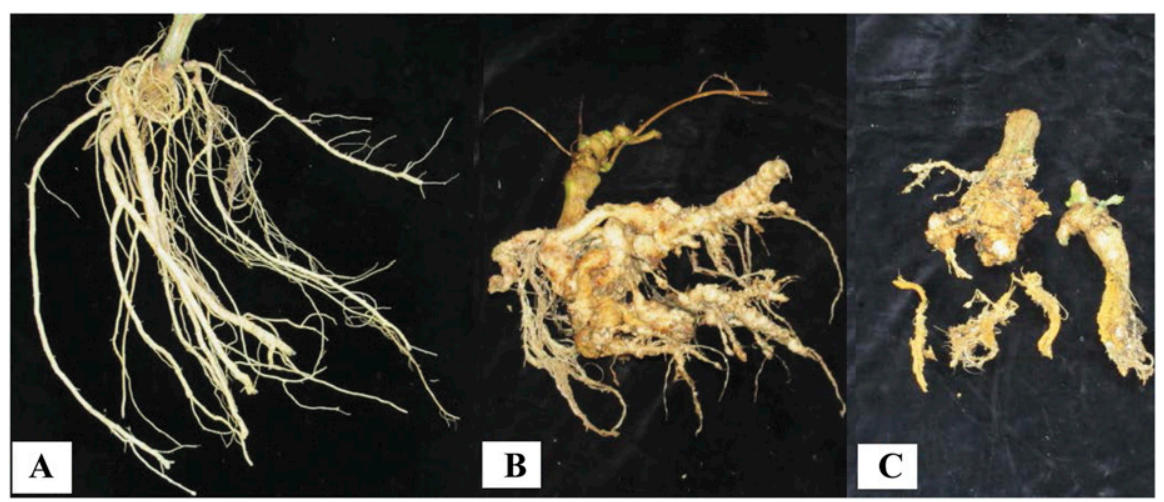

Fig. 4. Roots of USVL-360 (A), 'Emphasis' (B), and 'Shintosa Camel' (C) rootstocks grown in a field in Charleston, SC, naturally infested with root-knot nematodes. The USVL-360 roots are overall healthy and show little or no damage, whereas the 'Emphasis' and 'Shintosa Camel' roots are heavily damaged by root-knot nematodes.

Table 2. Gall indices (GI), egg mass indices (EMI), and fibrous root indices (FRI) for tetraploid line USVL360, its diploid parent Citrullus lanatus var. citroides (CLC) PI 299379 (homozygous line 11129), CLL PI 500331, heirloom watermelon 'Charleston Gray', and the hybrid squash rootstock 'Strong Tosa' inoculated with 2500 eggs of M. incognita race 3 in a replicated greenhouse test ${ }^{2}$ at the U.S. Vegetable Laboratory, Charleston, SC (Summer 2012).

\begin{tabular}{lccccc}
\hline & USVL-360 & PI 299379 & PI 500331 & Charleston Gray & Strong Tosa \\
\hline GI & $2.19 \mathrm{~b}^{\mathrm{y}}$ & $1.96 \mathrm{~b}$ & $2.01 \mathrm{~b}$ & $3.99 \mathrm{a}$ & $4.61 \mathrm{a}$ \\
EMI & $1.04 \mathrm{~b}$ & $1.07 \mathrm{~b}$ & $1.03 \mathrm{~b}$ & $1.85 \mathrm{~b}$ & $4.07 \mathrm{a}$ \\
FRI & $2.09 \mathrm{~b}^{\mathrm{x}}$ & $2.34 \mathrm{~b}$ & $2.49 \mathrm{~b}$ & $3.52 \mathrm{a}$ & $2.17 \mathrm{~b}$ \\
\hline
\end{tabular}

${ }^{\mathrm{z}}$ Means of seven replicates $(\mathrm{N}=7)$.

${ }^{\mathrm{y}}$ Gall and egg mass indices were rated on a scale of 1 to 5 where $1=0 \%$ to $3 \%$ root system galled or covered with egg masses, $2=4 \%$ to $25 \%, 3=26 \%$ to $50 \%, 4=51 \%$ to $79 \%$, and $5=80 \%$ to $100 \%$ root system galled or covered with egg masses). Mean separation within rows by Fisher's protected least significant test, $P \leq 0.05$. ${ }^{x}$ Roots were rated for percentage of fibrous roots on a 1 to 5 scale where $1=0 \%$ to $3 \%$ root system had fibrous roots, $2=4 \%$ to $25 \%, 3=26 \%$ to $50 \%, 4=51 \%$ to $79 \%$, and $5=80 \%$ to $100 \%$ root system had fibrous roots. Mean separation within rows by Fisher's protected least significant test, $P \leq 0.05$. also be submitted to the National Plant Germplasm System where it will be available for research purposes, including the development and commercialization of new tetraploid watermelon lines for use in development of triploid seedless watermelon cultivars. It is requested that appropriate recognition of the source be given when this germplasm contributes to research or development of a new breeding line or cultivar.

\section{Literature Cited}

Ascough, G.D., J. van Staden, and J.E. Erwin. 2008. Effectiveness of colchicine and oryzalin at inducing polyploidy in Watsonia lepida N.E. Brown. HortScience 43:2248-2251.

Cohen, R., J. Tyutyunik, E. Fallik, Y. Oka, Y. Tadmaor, and M. Edelstein. 2014. Phytopathological evaluation of exotic watermelon germplasm as basis for rootstock breeding. Sci. Hort. 165:203-210.

Contreras, R.N., J.M. Ruter, and B.M. Schwartz. 2010. Oryzalin-induced tetraploidy in Cryptomeria japonica (Cupressaceae). HortScience 45:316-319.

Edelstein, M., J. Tyutyunik, E. Fallik, A. Meir, Y. Tadmor, and R. Cohen. 2014. Horticultural evaluation of exotic watermelon germplasm as potential rootstocks. Sci. Hort. 165:196-202.

Guo, S., J. Zhang, H. Sun, J. Salse, W.J. Lucas, H. Zhang, Y. Zheng, L. Mao, Y. Ren, Z. Wang, J. Min, X. Guo, F. Murate, B. Ham, Z. Zhang, S. Gao, M. Huang, Y. Xu, S. Zhong, A. Bombarely, L.A. Mueller, H. Zhao, H. He, Y. Zhang, Z. Zhang, S. Huang, T. Tan, E. Pang, K. Lin, Q. Hu, H. Kuang, P. Ni, B. Wang, J. Liu, Q. Kou, W. Hou, X. Zou, J. Jiang, G. Gong, K. Klee, H. Schoof, Y. Huang, X. Hu, S. Dong, D. Liang, J. Wang, K. Wu, Y. Xia, X. Zhao, Z. Zheng, M. Xing, X. Liang, B. Huang, T. Lv, J. Wang, Y. Yin, H. Yi, R. Li, M. Wu, A. Levi, X. Zhang, J.J. Giovannoni, J. Wang, Y. Li, Z. Fei, and Y. $X u$. 2013. The draft genome of watermelon (Citrullus lanatus) and resequencing of 20 diverse accessions. Nat. Genet. 45:51-58.

Harris, K.R., W.P. Wechter, and A. Levi. 2009. Isolation, sequence analysis, and linkage mapping of NBS-LRR disease resistance gene analogs in watermelon. J. Amer. Soc. Hort. Sci. 134:649-657.

Levi, A., J.A. Thies, W.P. Wechter, H.F. Harrison, A.M. Simmons, U. Reddy, P. Nimmakayala, and Z. Fei. 2013. High frequency oligonucleotides-Targeting active gene (HFO-TAG) markers reveal wide genetic diversity among Citrullus spp. accessions useful for enhancing disease or pest resistance in watermelon cultivars. Genet. Resources Crop Evol. 60:427-440.

Levi, A., J.A. Thies, W.P. Wechter, C.S. Kousik, K. Ling, H.F. Harrison, Jr., A.M. Simmons, U.K. Reddy, P. Nimmakayala, and Z. Fei. 2012. Exploiting genetic diversity in Citrullus spp. to enhance watermelon cultivars, p. 41-48. In: Sari, N., I. Solmaz, and V. Aras (eds.). Proc. of the $X^{\text {th }}$ EUCARPIA Meeting on Genetics and Breeding of Cucurbitaceae. Çukurova University, Adana, Turkey.

Thies, J.A., J. Ariss, R.L. Hassell, and A. Levi. 2012. Root-knot nematode resistant rootstocks for grafted watermelon, p. 201-211. In: Sari, N., I. Solmaz, and V. Aras (eds.). Proc. of the $X^{\text {th }}$ EUCARPIA Meeting on Genetics and Breeding of Cucurbitaceae. Çukurova University, Adana, Turkey.

Thies, J.A., J.J. Ariss, R.L. Hassell, S. Olsen, C.S. Kousik, and A. Levi. 2010. Grafting for 
management of southern root-knot nematode, Meloidogyne incognita, in watermelon. Plant Dis. 94:1195-1199.

Thies, J.A., S.A. Buckner, M.I. Horry, R.L. Hassell, and A. Levi. 2014. Influence of Citrullus lanatus var. citroides rootstocks and their F1 hybrids on yield and response to root-knot nematode, Meloidogyne incognita, in grafted watermelon. HortScience (in press).
Thies, J.A. and A. Levi. 2007. Characterization of watermelon (Citrullus lanatus var. citroides) germplasm for resistance to root-knot nematodes. J. Nematol. 42:1530-1533.

United States Department of Agriculture Economics, Statistics and Market Information System. 2012 4 Feb. 2014. <http://usda.mannlib.cornell.edu>.

Wechter, W.P., C. Kousik, M. McMillan, and A. Levi. 2012. Identification of resistance to
Fusarium oxysporum f. sp. niveum race 2 in Citrullus lanatus var. citroides Plant Introductions. HortScience 47:334-338.

Whitaker, T.W. and G.N. Davis. 1962. Cucurbits: Botany, cultivation, and utilization. Interscience Publishers, Inc., New York, NY.

Whitaker, T.W. and W.B. Bemis. 1976. Cucurbits. p. 64-69. In: N.W. Simmonds (ed.). Evolution of crop plants. Longman, London. 